\title{
Relationship between electrical conductivity, softening and color of Fuerte avocado fruits during ripening
}

\author{
Dorria M. Ahmed ${ }^{1}$; AmI R.M Yousef ${ }^{2}$ and H S.A. Hassan ${ }^{1}$ \\ ${ }^{1}$ Pomology Department, National Research Center, El-Behooth, Dokki, Egypt. \\ ${ }^{2}$ Horticultural Crops Technology Department, National Research Center, El-Behooth, Dokki, \\ Egypt.
}

\begin{abstract}
To identify the most important ripening parameters of Fuerte avocado fruits, and to quantify the relationship between color changes, electrical conductivity and softening of avocado fruits, the ripening process was investigated to fulfill the consumer and market demands. Mature and high quality avocado fruits (Persea Americana Mill.) were held to ripe at $20^{\circ} \mathrm{C}$ in controlled temperature rooms with $90-95 \%$ relative humidity for two weeks. Fruit quality characteristics (respiration rate, soluble solids content (SSC), total acidity (TA), ascorbic acid and oil content) during ripening period at $20^{\circ} \mathrm{C}$ were evaluated. Moreover, ripening parameters as color changes, chlorophyll contents, fruit firmness and electrical conductivity and ripening enzymes (CX and PME) were also investigated throughout ripening process. During ripening period for 2 weeks at $20^{\circ} \mathrm{C}$, fruit quality criteria showed that respiration rate and oil content had a noticeable significant increase with the ripening increase. While, acidity (TA), soluble solids (SSC) and ascorbic acid content cleared a slight and significant decrease. Throughout color development, the three parameters lightness $\left(L^{*}\right)$, hue $\left(h^{\circ}\right)$ and chroma $\left(C^{*}\right)$ changed significantly, hue decreased little, lightness moderately, while chroma changed more quickly. Moreover, an significant decline in chlorophyll $\mathrm{a}$ and $\mathrm{b}$ concentration occurred and reflected to color changes during ripening process. For ripening enzyme activities, Fuerte avocado fruits showed a great increase in cellulase activity compared with gradual decrease in Pectinmethylesterase activity after ripening. Avocado fruit firmness markedly reduced gradually after harvest till ripening at $20^{\circ} \mathrm{C}$, and this decline was positively correlated with an increase of electrical conductivity of the fruit tissue suggesting a gradual loss of cell membrane integrity. This increase in conductivity was promoted by ripening process. These results have allowed us to set that ripening process had some parameters were simple and rapid to measure as ripening indices. We conclude that in Fuerte avocado fruits, electrical conductivity (EC) can serve as a good indicator of membrane permeability and that it is highly correlated with ethylene production, softening and also demonstrates a relationship between firmness and EC.
\end{abstract}

Keywords: Avocado, ripening, electrical conductivity, softening, color, chlorophyll, cellulase and pectinmethylesterase

\section{INTRODUCTION}

The avocado (Persea americana Mill.) is an important fruit with a high market value, but with a relatively short storage life. (Hershkovitz et al. 2005) The Fuerte avocado is a typical climacteric fruit will not ripen while attached to the tree.. Ripening and senescence of climacteric plant tissues are characterized by a burst of ethylene production (Feng et al 2005 and Hershkovitz et al., 2009). It is involves a series of coordinated metabolic events which alter their anatomy, biochemistry, physiology, and gene expression (Giovannoni, 2001). These alterations affect many characteristics, such as color, flavor and texture of the fruit (Cai et al., 2006).

Softening is an important part of the ripening process, and it is well documented that change in cell walls accompany fruit softening (Brummell and Harpster, 2001). Similarly, softening time as the sole criterion of ripening is very important in the marketing of avocados (Gertman and Fuchs 1974). In parallel with the pulp firmness, electrical parameter, color and fruit quality and enzyme activities were obtained to estimate the time course of ripening in avocado. (Montoya et al., 1994 and Ergun et al., 2005). 
Color is an important food quality parameter. It affects consumer acceptance, the perception of sweetness and flavor and can even evoke emotional feelings in humans (Bayarri et al., 2001; Crisosto et al., 2003 and Ornelas et al., 2008). During 'Fuerte' ripening color play an important role in the perception of overall quality. We may be able to manipulate colouring in some way to better co-ordinate softening and color change (Woolf and Laing, 1996). During ripening, the skin color of 'Hass' avocado changes from green to purple/ black. It is important for industry and consumers as an indication of fruit ripeness (Cox et al., 2004). Moreover, changes in chlorophyll concentrations in relation to fruit firmness at ripening temperature $\left(20^{\circ} \mathrm{C}\right)$ is also studied as an indicator of ripeness for avocado fruit quality parameters (Cai et al., 2006 Palapola et al., 2009).

Membrane leakage in avocado fruit, as evaluated from electrical conductivity (EC) measurements, increased during cold storage and ripening (Montoya et al., 1994). High conductivity is indicative of leakage of intracellular ions and, therefore, damage to membranes. Electrical conductivity can be used effectively as a physical maturity index, and it is a suitable index of storage quality. (Feng et al 2005). The delay of ripening was associated with reductions in fruit softening and in electrical conductivity (EC), the latter being an indicator of membrane permeability (Hershkovitz et al. 2005).

Cellulase and Pectinmethylesterase activities which is synthesized at the onset of ripening (Christoffersen et al., 1984) is well discussed and was suggested to closely relate to the avocado fruit softening. Activity was first detected near the endocarp of the fruit. As the fruit ripened, the activity progressively increased across the mesocarp tissue towards the exocarp. (Robert and Nancy1983). On the other side Pectinmethylesterase is believed to have little effect on wall softening (Brady 1976) serving only to cause partial demethylation allowing PG activity.

Therefore, the objective of the present work was to identify the most important ripening parameters of Fuerte avocado fruits, and to quantify the relationship between color changes, electrical conductivity and softening of avocado fruit during ripening process.

\section{MATERIAL AND METHODS}

Fruits: Avocado fruits cv. Fuerte (Persea Americana Mill) were obtained from a private orchard (Nemous), Giza governorate, Egypt. Fruits were harvested at the first November of 2007 and 2008 from trees were 20 years old. Fruits collected at the maturity stage after $185-200$ days from full bloom, its weight $280-300 \mathrm{gm}$,
$80 \%$ moisture content and $12.9-13.5 \%$ oil. graded, packed and transport to the laboratory of ADS project in Cairo University.

Treatment: On arrivalof the lab., Fuerte avocado fruits were selected, washed, air dried, packed in carton boxes and held to ripe at $20^{\circ} \mathrm{C}$ in controlled temperature rooms with $90-95 \%$ relative humidity for two weeks. Three replicates for each sampling date (3 days) were used and each replicate consisted of 5 fruits. Fruits quality measurements were assessed after ripening at $20^{\circ} \mathrm{C}$ in each sampling date.

Respiration rate: Fruits of each sampling date were weighed and placed in 2-liter sealed jars at $20^{\circ} \mathrm{C} . \mathrm{O}_{2}$ and $\mathrm{CO}_{2}$ production samples of the jars headspace were injected into Servomex Inst (Model 1450C-Gas Analyzer). Respiration rate was calculated as $\mathrm{ml} \mathrm{CO}_{2}$ / kg / hr). (Pesis and Ben-Arie, 1984 and Lurie \& Pesis, 1992;).

Fruit quality assessment: Freshly prepared juice of avocado fruits samples were used for TSS, TA ascorbic acid and oil content determinations as described by A.O.A.C. (1990). TA were expressed as oleic acid, while ascorbic acid was measured using 2 , 6 dichlorophenol indophenol titration. Oil content of the dried flesh samples was determined too and expressed as percentage.

Color meserments: Color was measured with a Minolta colorimeter (Minolta Co. Ltd., Osaka, Japan) on the basis of the CIELAB color system $\left(L^{*}, a^{*}, b^{*}\right.$, $C^{*}$, and $\left.h^{\circ}\right)$. In this system $L^{*}, a^{*}$ and $b^{*}$ describe a three dimensional space, where $L^{*}$ (Lightness) is the vertical axis and its value varies from 100 , for perfect white, to zero, for black. Values of $a^{*}$ and $b^{*}$ specify the green-red and blue-yellow axis, respectively. Chroma $\left(C^{*}\right)$ describes the length of the color vector in the plane formed by the values of $a^{*}$ and $b^{*}$, while Hue $(h \circ)$ determines the position of such vector. $C^{*}$ and $h \circ$ values are calculated based on $a^{*}$ and $b^{*}$ values according to the following equations: $\boldsymbol{C}^{*}=$ $\left[\left(a^{*}\right)^{2}+\left(b^{*}\right)^{2}\right] 0.5$ and $h_{\circ}=180-\tan ^{-1}\left(b^{*} / a^{*}\right)$. Five fruits were measured objectively by averaging three measurements taken around the fruit equator, either in mesocarp and endocarp. Color was longitudinally determined on two points of each fruit (McGuire, 1992).

Chlorophyll content: - Chlorophyll content was measured by extracting the pigments from the peel with acetone and measuring the color with a spectrophotometer (Bausch \& Lamb Co. USA) at 660 and $640 \mathrm{~nm}$. Chlorophyll $a$ and $b$ contents were calculated according to (Lichtenthaler and Wellburn, 1983). 
Agric. Biol. J. N. Am., 2010, 1(5): 878-885

Fruit firmness: Fruit firmness was determined using Ametek pressure tester. Firmness of 5 fruits from each replicate was measured at two opposite points on the equator of each fruit. Results were calculated as Newton units (A.O.A.C., 1990).

Electrical conductivity: Five avocado fruits from each sample were used for the determination of tissue electrolyte leakage. Using a cork borer, the disks rind were removed from the fruit with $10 \mathrm{~mm}$ in diameter. The initial electrolyte leakage was assessed following incubation of five disks in $25 \mathrm{ml}$ of $0.4 \mathrm{~m}$ mannitol at $23+2^{\circ} \mathrm{C}$ for $2 \mathrm{~h}$ with constant shaking. Electrical conductivity of the bathing solution was measured using a conductivity meter. The tissue was then autoclaved for 20 min, held overnight, and total conductivity was measured. Electrolyte leakage was calculated as initial/total $\times 100$ and expressed as $\mathrm{ml} / \mathrm{mohs}$ (Montoya et al., 1994).

Cellulase and Pectinmethylestrase activities: Mesocarp fruit were extracted for cellulase (CX) activity with carboxy methyl and citrate buffer $(\mathrm{pH}$ 4.8) using 3, 5-dinitrosalicylic acid (DNS) reagent. The color was measured at wavelength of $5 \% \mathrm{~nm}$ with the above spectrophotometer. Data were expressed as one unit of Cellulase activity liberates 1 Mmol glucose in milliliter per min (Miller, 1959 and Vaheri et al, 1979). Pectinmethylestrase (PME) was determined by titrating the release of carboxyl groups by the action of PME on the substrate with $0.095 \mathrm{~N}$ $\mathrm{NaOH}$ at $(\mathrm{pH} 7.58)$ for $5 \mathrm{~min}$ at $10^{\circ} \mathrm{C}$. PME units were expressed in meq of ester hydrolyzed $/ \mathrm{m}$ in $\mathrm{g}$ fresh weight (Rouse and Atkins, 1955).

Statistical analysis: The design for this experiment was a completely randomized design (CRD) with three replications. Data were analyzed with the

Table 1: Fuerte avocado fruit quality criteria (Respiration rate, soluble solids content, total acidity, vitamin $C$ and oil content during ripening at $20^{\circ} \mathrm{C}$. analysis of variance (ANOVA) procedure of MSTAT$C$ program. When significant differences ( $P>0.05)$ were detected, data was treated by analysis of variance with standard deviation (Steel and Torrie, 1980).

\section{RESULTS AND DISCUSSION}

Fruit quality criteria: Changes in Fuerte avocado fruit quality parameters, are depicted in (Table.1).Throughout ripening period at $20^{\circ} \mathrm{C}$ for two weeks, respiration rate was expressed as mass of $\mathrm{CO}_{2}$ in $\mathrm{mg} / \mathrm{kg} / \mathrm{h}$ are noticeable significantly increased with the ripening increase. Changes in titratable acidity (TA) and soluble solid concentration (SSC) cleared a slight and significant decrease. Moreover, ascorbic acid content showed a slight and non significant decrease, while oil content appeared a gradual and significant increase throughout ripening period at $20^{\circ} \mathrm{C}$ for 2 weeks.

In looking to identify the controls of ripening and senescence in avocado fruit which such a relatively short postharvest life, it is of interest to explore the dynamics of ethylene production and softening, and thus extend storage life. Our results are in agreement with (Eaks, 1976; Medicott et al., 1986 and Jacobi et al., 2000). They reported that an atypical climacteric respiratory pattern which was associated with ripening. TA was an indicator of the degree of fruit ripeness and SSC no longer accumulation in fruit tissues. According to this could be associated with the higher rate of respiration substrate for the catabolic process in avocado and mangoes respectively. Zambrano, (2000), noticed that ascorbic acid declined during ripening and storage of mango fruit. Moreover, (Olaeta et al., 1986; Eaks, 1990 and Ergun et al., 2005) explained that Fuerte avocado fruit were richer in oil content than Hass fruit and oil content increased in high quality ripe fruit.

\begin{tabular}{|c|c|c|c|c|c|c|c|}
\hline \multirow{2}{*}{$\begin{array}{l}\text { Fruit Quality } \\
\text { Characteristics }\end{array}$} & \multicolumn{7}{|c|}{ Ripening days at $20^{\circ} \mathrm{C}$} \\
\hline & 0 & 3 & 6 & 9 & 12 & 15 & L.S.D at 0.05 \\
\hline $\begin{array}{l}\text { Respiration rate } \\
(\mathrm{m} / \mathrm{kg} / \mathrm{hr})\end{array}$ & 18.03 e \pm 2.03 & $22.43 \mathrm{~cd} \pm 0.93$ & $28.65 a b \pm 2.05$ & $30.11 a \pm 3.01$ & $25.13 b c \pm 2.13$ & 20.93 de \pm 2.93 & 4.068 \\
\hline $\begin{array}{l}\text { Soluble Solids } \\
\text { Content (SSC\%) }\end{array}$ & $10.93 a \pm 1.44$ & $10.77 a \pm 1.55$ & $9.97 a b \pm 0.59$ & $8.37 b c \pm 0.31$ & $7.13 c \pm 0.814$ & $6.49 c \pm 1.39$ & 1.986 \\
\hline $\begin{array}{l}\text { Titratable Acidity } \\
(\text { TA \%) }\end{array}$ & $1.09 a \pm 0.17$ & $0.94 a b \pm 0.18$ & 0.86 bc \pm 0.06 & $0.88 \mathrm{abc} \pm 0.08$ & $0.67 \mathrm{~cd} \pm 0.10$ & $0.56 \mathrm{~d} \pm 0.12$ & 0.225 \\
\hline $\begin{array}{l}\text { Vitamin C } \\
(\mathrm{mg} / 100 \mathrm{gm})\end{array}$ & $10.44 \pm 0.79$ & $8.77 \pm 1.44$ & $8.46 \pm 0.94$ & $7.21 \pm 1.09$ & $7.21 \pm 1.96$ & $6.21 \pm 2.12$ & NS \\
\hline Oil Content (\%) & $45.68 d \pm 1.54$ & $47.55 \mathrm{~cd} \pm 1.96$ & 49.08 bcd \pm 1.77 & $50.36 a b c \pm 2.58$ & $51.60 a b \pm 2.73$ & $53.65 \mathrm{a} \pm 1.45$ & 3.670 \\
\hline
\end{tabular}


Agric. Biol. J. N. Am., 2010, 1(5): 878-885
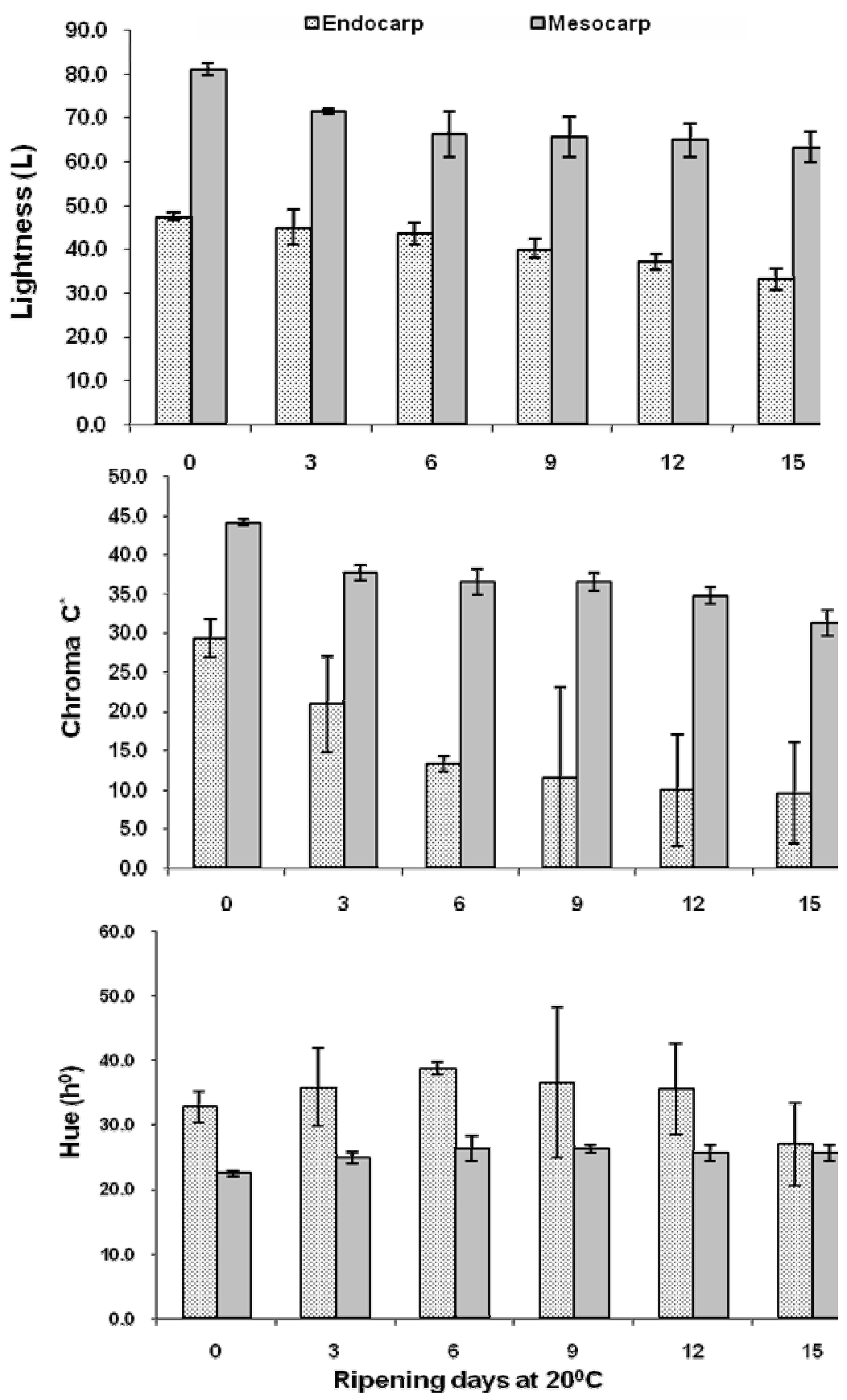

Fig. 1: Endocarp and mesocarp_of Fuerte avocado fruits ripened at $20^{\circ} \mathrm{C}$ for two weeks.

Values are the means of 3 replicates and each of 10 and 5 fruits respectively. The vertical bar represents a mean \pm S.D. 
Agric. Biol. J. N. Am., 2010, 1(5): 878-885

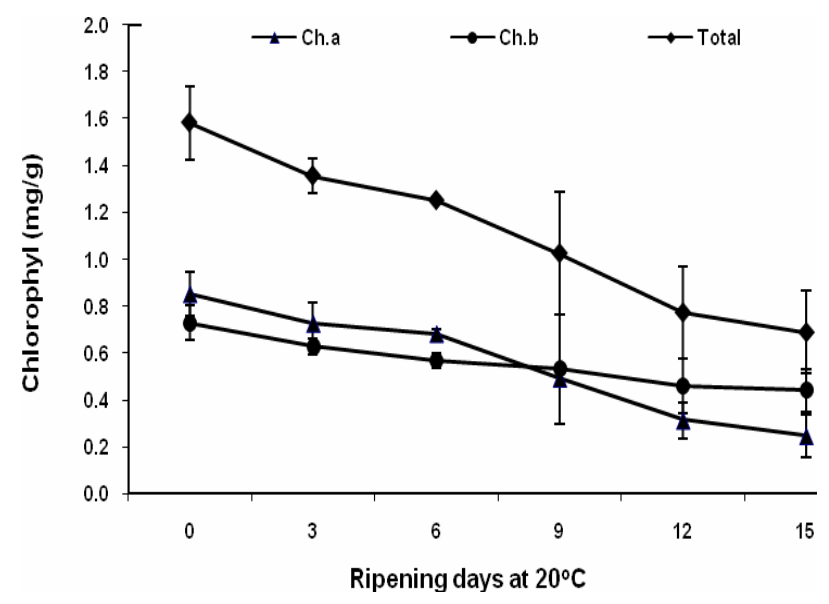

Fig. 2: Changes in total chlorophyll and chlorophyll a and b of Fuerte avocado fruits ripened at $20^{\circ} \mathrm{C}$ for two weeks. Values are the means of 3 replicates and each of 10 and 5 fruits respectively. The vertical bar represents a mean \pm S.D.

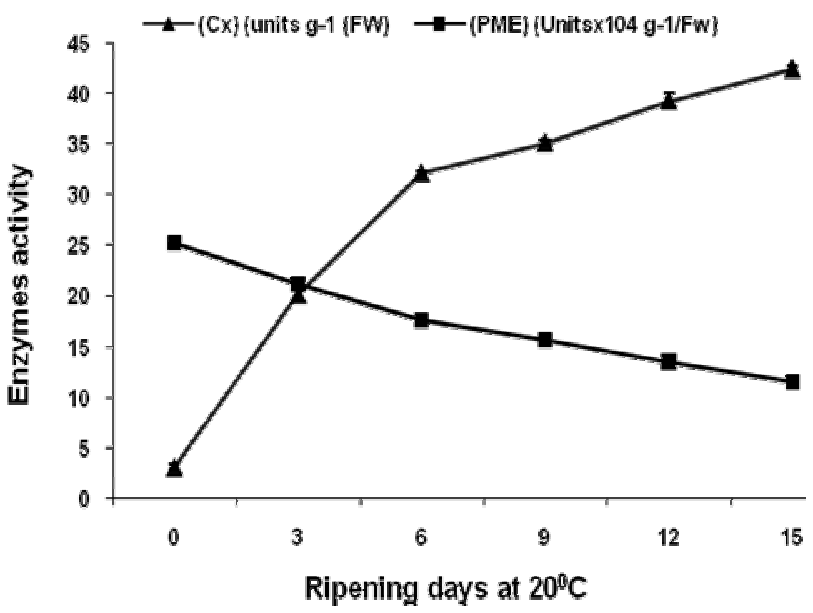

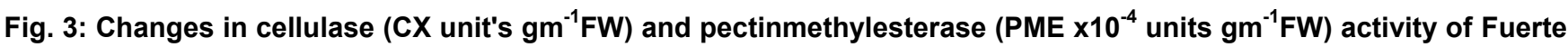
avocado fruit fruits ripened at $20^{\circ} \mathrm{C}$ for two weeks.

Values are the means of 3 replicates. The vertical bar represents a mean of \pm S.d.

\section{Fruit color and Chlorophyll content:}

During ripening of Fuerte avocado fruits at $20^{\circ} \mathrm{C}$, there was a noticeable decrease of the intensity of color of the endocarp and mesocarp. These reduction was accompanied by a decrease in the values of $a^{*}$, $b^{*}$, and a gradual decrease in the values of lightness $\left(L^{*}\right)$, hue $\left(h^{\circ}\right)$ and chroma $\left(C^{*}\right)$. Throughout color development, the three parameters changed significantly, hue decreased little, lightness moderately, while chroma changed more quickly (Fig.1) and were correlated with visual color ratings. Moreover, an significant decline in chlorophyll a and b concentration occurred and reflected to color changes during ripening process as (Fig. 2).

Our results are in harmony with those obtained by (Cox et al., 2004) in Hass avocado fruits who found that the color pattern of avocado ripening at 15, 20 and $25^{\circ} \mathrm{C}$ as measured by these three parameters $\left(L^{*}, C^{*}\right.$ and $\left.h^{\circ}\right)$ decreased with ripening and was somewhat different. Similar behaviors for $a^{*}, b^{*}$ and $L^{*}$ have been reported during the ripening of mango cultivars. (Bender et al., 2000 and Ornelas-Paz et al., 2008). Also, (Lancaster, et al., 1997) decided that as chroma $\left(C^{*}\right)$ increases, color becomes more intense 
in apple and peaches fruits and noticed that a significant linear relationship was detected between log (chlorophyll) and $L^{*}$, indicating a logarithmic relationship between increasing chlorophyll and darkness of tissue

\section{Cellulase and Pectinmethylesterase activities during ripening at $20^{\circ} \mathrm{C}$ :}

Fuerte avocado fruits showed a great increase in cellulase activity which reached 42.48 units /gm FW after two weeks of ripening at $20^{\circ} \mathrm{C}$ compared with the initial value of 3.15 units $/ \mathrm{gm} \mathrm{FW}$ at harvest. Meanwhile Pectinmethylesterase activity decreased gradually after ripening recorded its least value 11.59 $\mathrm{x} 1^{04}$ units /gm FW after 15 days of ripening at $20^{\circ} \mathrm{C}$ compared to its activity at harvest $25.23 \times 10^{-4}$. units Igm FW as illustrated in (Fig. 2).

These results support those of Awad and Young, (1979) on avocado and Robert and Nancy (1983) on papaya fruits. They reported that cellulase activity in the preclimacteric fruit, started to increase just as respiration increased and reached a level two times greater than at the edible soft stage of avocado and papaya fruits. On the opposite side, pectinmethyl esterase (PME) activity were high at the start of fruit ripening and declined steeply till the beginning of softening and early in the climacteric fruits (Koslanund et al., 2005).

Fruit firmness and Electrical Conductivity: Our results in (Table. 2) showed that avocado fruit firmness decreased gradually after harvest till ripening at $20^{\circ} \mathrm{C}$, and this decline was positively correlated with an increase of electrical conductivity of the fruit tissue. Altering the rate of senescence correspondingly altered the rate of fruit softening. In addition, The electrical conductivity (EC) of the fruit tissue continually increased after harvest, suggesting a gradual loss of cell membrane integrity. This increase in conductivity was promoted by ripening process. The EC values were $3.89 \mathrm{ml} / \mathrm{mohs}$ in ripening fruits after 2 weeks at $20^{\circ} \mathrm{C}$. EC levels increased about six-fold than its value at the initial time $(0.63 \mathrm{ml} / \mathrm{mohs})$ of ripening at $20^{\circ} \mathrm{C}$. The EC of the fruit tissue showed a very significant positive correlation with fruit firmness, reached its edible eating (ripe) value $(10.75 \mathrm{~N})$ after two weeks of ripening.

These results support those of Cai et al., (2006) who reported a reduction in the firmness of loquat fruit increased steadily during shelf life after harvest, and this increase was enhanced by ethylene treatment and delayed by 1-MCP application. Meanwhile, Hershkovitz et al., (2005 and 2009) showed that the delay of ripening of avocado fruit was associated with reductions in fruit softening and in electrical conductivity (EC), the latter being an indicator of membrane permeability. In this concern Sarang et al., (2008) found that the increase in electrical conductivity is a further indication of increasing senescence of the tissue. (Montoya et al., 1994; Castro et al. 2004 and Feng et al., 2005) added that in avocado fruit, EC has been shown to serve as a good indicator of membrane permeability, and to be highly correlated with ethylene production, softening, and $\mathrm{Cl}$ symptoms. Thus, electrical conductivity seems to be a suitable index of avocado condition during cold-storage and ripening. The curve of electrical conductivity is tentatively explained by an increase in release of ions due to biochemical changes occurring during ripening. The onset of a steep rise in conductivity was followed by softening and reflected the beginning of the ripening process. Moreover the electrical conductivity peak rose at the same time as the ethylene peak. (Montoya et al., 1994; Hershkovitz et al., 2005 ; Cai et al., 2006 and Hershkovitz et al., 2009).

Table 2: Fruit firmness and electrical conductivity of Fuerte avocado fruits during ripening at $20^{\circ} \mathrm{C}$.

\begin{tabular}{|l|c|c|c|c|c|c|c|}
\hline \multirow{2}{*}{$\begin{array}{l}\text { Fruit Quality } \\
\text { Characteristics }\end{array}$} & 0 & 3 & 6 & 9 & 12 & 15 & $\begin{array}{l}\text { L.S.D at } \\
0.05\end{array}$ \\
\cline { 2 - 8 } & $77.24 \mathrm{a} \pm 1.24$ & $75.61 \mathrm{a} \pm 1.94$ & $45.09 \mathrm{~b} \pm 0.98$ & $14.82 \mathrm{c} \pm 1.24$ & $12.30 \mathrm{~d} \pm 0.75$ & $10.75 \mathrm{~d} \pm 0.90$ & 2.203 \\
\hline Firmness (N) & $0.63 \mathrm{f} \pm 0.067$ & $0.89 \mathrm{e} \pm 0.060$ & $1.63 \mathrm{~d} \pm 0.141$ & $2.98 \mathrm{c} \pm 0.156$ & $3.51 \mathrm{~b} \pm 0.104$ & $3.89 \mathrm{a} \pm 0.92$ & 0.1949 \\
\hline $\begin{array}{l}\text { Electrical } \\
\begin{array}{l}\text { Conductivity } \\
\text { EC / (m.mohs/cm) }\end{array}\end{array}$ & & & &
\end{tabular}


Agric. Biol. J. N. Am., 2010, 1(5): 878-885

Table 3: Fruit ripening indices of Fuerte avocado fruits after two weeks at $20^{\circ} \mathrm{C}$.

\begin{tabular}{lccccc}
\hline \multirow{2}{*}{ Treatments } & \multicolumn{5}{c}{ Fruit ripening Parameters } \\
\cline { 2 - 7 } & Firmness $(\mathrm{N})$ & $\mathrm{EC}(\mathrm{m} . \mathrm{mohs} / \mathrm{cm})$ & Oil percent & Enzyme $(\mathrm{CX})$ & Enzyme $(\mathrm{PM})$ \\
\hline Un ripe fruits & $77.24 \mathrm{a} \pm 0.93$ & $0.63 \mathrm{~b} \pm 0.07$ & $45.68 \mathrm{a} \pm 1.538$ & $3.15 \mathrm{~b} \pm 0.27$ & $25.23 \mathrm{a} \pm 0.37$ \\
\hline Ripe fruits & $10.75 \mathrm{~b} \pm 0.62$ & $3.89 \mathrm{a} \pm 0.50$ & $53.65 \mathrm{~b} \pm 1.447$ & $42.48 \mathrm{a} \pm 0.35$ & $11.59 \mathrm{~b} \pm 0.51$ \\
\hline L.S.D at 0.05 & 1.789 & 0.8047 & 3.385 & 0.706 & 1.019 \\
\hline
\end{tabular}

Table 4: Color ripening indices of Fuerte avocado fruits after two weeks at $20^{\circ} \mathrm{C}$

\begin{tabular}{|l|l|l|l|l|c|c|}
\hline \multirow{2}{*}{ Treatments } & \multicolumn{5}{|c|}{ Fruit Color Parameters } \\
\cline { 2 - 7 } & Lightness $\left(\mathrm{L}^{*}\right)$ & Chroma $\left(\mathrm{C}^{*}\right)$ & Hue $\left(\mathrm{h}^{*}\right)$ & Ch. $\mathrm{a}$ & Ch. $\mathrm{b}$ & Total Ch. \\
\hline Un ripe fruits & $47.51 \mathrm{a} \pm 0.924$ & $29.30 \mathrm{a} \pm 2.785$ & $32.91 \mathrm{a} \pm 2.47$ & $0.853 \mathrm{a} \pm 0.095$ & $0.73 \mathrm{a} \pm 0.08$ & $1.58 \mathrm{a} \pm 0.16$ \\
\hline Ripe fruits & $33.2 \mathrm{~b} \pm 2.486$ & $9.54 \mathrm{~b} \pm 0.909$ & $27.10 \mathrm{a} \pm 6.45$ & $0.247 \mathrm{~b} \pm 0.092$ & $0.44 \mathrm{~b} \pm 0.09$ & $0.69 \mathrm{~b} \pm 0.18$ \\
\hline L.S.D at 0.05 & 4.241 & 4.696 & N.S & 0.2151 & 0.191 & 0.379 \\
\hline
\end{tabular}

\section{CONCLUSSION}

Our results showed a series of consistent changes that occur as avocado fruit pass through ripening and senescence after harvest (Table 3). The color change during ripening of 'Hass' avocados is due to an initial reduction in chlorophyll concentration. These pigment changes are highly correlated with skin color change, which is also influenced by the ripening process (Table 4). The presence of cellulase activity early in the ripening process may trigger some of the subsequent events. PME may act first to demethylate polygalacturunate and may be followed by the action of the other enzyme resulting in cell wall disassembly and fruit softening in avocado (Fig.3). The onset of a steep rise in conductivity was followed by softening and reflected the beginning of the ripening process. Moreover the electrical conductivity peak rose at the same time as the ethylene peak. In parallel with the electrical parameter, pulp firmness, and respiration rate were obtained to estimate the time course of ripening in avocado (Table 2). These results have allowed us to set that ripening process had some parameters were simple and rapid to measure as ripening indices. We conclude that in Fuerte avocado fruit electrical conductivity (EC) can serve as a good indicator of membrane permeability and that it is highly correlated with ethylene production and with softening and also demonstrates a relationship between firmness and EC.

\section{ACKNOWLEDGMENTS}

The authors are thankful for the financial support from the National Research Center (NRC). We also thank the members of Agricultural Development Systems project (ADS) for technical assistance

\section{REFERENCES}

Awad. M. and R.E. Young (1979). Postharvest variation in cellulase, polygalacturonase, and pectinmethylesterase in avocado (Persea americana Mill. cv. Fuerte) fruits in relation to respiration and ethylene production. Plant Physiol., 64:306-308.

A.O.A.C. (1990). Official methods of analysis. Association of Official Analytical Chemists. Washington, DC. U.S.A

Bayarri, S.; C. Calvo ; E. Costell and, L. Dur'an (2001). Influence of color perception of sweetness and fruit flavor of fruit drinks. Food Sci. Tech. Int. 7:399-404.

Bender, R. J.; J. K. Brecht; S. A. Sargent ; and D.J. Huber (2000). Mango Tolerance to Reduced Oxygen Levels in Controlled Atmosphere Storage. J. Amer. Soc. Hort. Sci. 125 (6): 707-713.

Brady, C.J. (1976). The pectinesterase of pulp of banana fruit. Aust. J. Plant Physiol.3:163-172.

Brummell, D. A. and M. H. Harpster (2001). Cell wall metabolism in fruit softening and quality and its manipulation in transgenic plant. Plant Mol. Biol.47:311340.

Cai, C.; K. S. Chen; W. P. Xu; W. S. Zhang; X. Li and I. Ferguson (2006). Effect of 1-MCP on postharvest quality of loquat fruit. Post. Biol. \& Technol. 40: 155-162.

Castro, I.; J.A. Teixeira ; S. Salengke ; S.K. Sastry and A.A. Vicente (2004). Ohmic heating of strawberry products: electrical conductivity measurements and ascorbic acid degradation kinetics. Innovative Food Science and Emerging Technologies 5: 27-36.

Christoffersen, R.E.; M. L. Tucker and G.G. Laties (1984). Cellulase gene expression in ripening avocado fruit. The accumulation of Cellulase mRNA and protein as demonstrate by bridization and immunodetection.Plant Mol. Biol.3:385-392.

Cox, K. A.; T. K. McGhie ; A. White and A. B. Woolf (2004). Skin color and pigment changes during ripening of 'Hass' avocado fruit. Post. Biol. \& Tech. 31: 287-294. 
Crisosto, C.H.; G.M. Crisosto and P. Metheney (2003). Consumer acceptance of 'Brooks' and 'Bing' cherries is mainly dependent on fruit SSC and visual skin color. Postharvest Biol. Technol. 28, 159-167.

Eaks, I. L. (1976). Ripening, chilling injury and respiratory response of 'Hass' and 'Fuerte' avocado fruits at $20^{\circ} \mathrm{C}$ following chilling. J. Am. Soc. Hort. Sci., 10:538-540.

Eaks, I.L. (1990). Change in the fatty acid composition of avocado fruit during ontogeny, cold storage and ripening. Acta Hort., 269:141-152.

Ergun, M.; S. A. Sargent; A. J. Fox;, J. H. Crane and D. J. Huber (2005). Ripening and quality responses of mamey sapote fruit to postharvest wax and 1-methylcyclopropene treatments. Postharvest Biology and Technology 36 (2005) 127-134.

Feng, G.; H. Yang and Y. Li (2005). Kinetics of relative electrical conductivity and orrelation with gas composition in modified atmosphere packaged bayberries (Myrica rubra Siebold and Zuccarini). LWT 38 :249-254.

Gertman, E. and Y. Fuchs (1974). Changes in pectinmethylesterase (PME) caused by ethylene applied at different temperatures. Plant Cell Physiol. 15:501-505.

Giovannoni, J. (2001). Molecular regulation of fruit ripening. Annu. Rev. Plant Physiol. Plant Mol. Biol. 52, 725-749.

Hershkovitz, V.; S. I. Saguy and E. Pesis (2005). Postharvest application of 1-MCP to improve the quality of various avocado cultivars. Post. Biol. \& Technol. 37: 252-264.

Hershkovitz, V.; H. Friedman; E.E. Goldschmid and E. Pesis (2009). The role of the embryo and ethylene in avocado fruit mesocarp discoloration. Journal of Experimental Botany, 60, (3): 791-799.

Jacobi, E.; A. Macrae and S.E. Hetherington (2000). Effects of hot air conditioning of Kensington mango fruit on response to hot water treatment. Postharvest Biol. Technol. 21:39-49.

Koslanund, R.; D. D. Archbold and K.W. Pomper (2005). Papaya (Asimina triloba L.) fruit ripening .1.Ethylene biosynthesis and production J. Amer. Soc. Hort. Sci., 130:638- 642.

Lancaster, J. E.; C.E. Lister; P.F. Reay and C. M. Triggs (1997). Influence of Pigment Composition on Skin Color in a Wide Range of Fruit and Vegetables. J. Amer. Sci. 122 (4) 594-598.

Lichtenthaler, $H_{\text {., }}$ an A. Wellburn (1983). Determinations of total carotenoids and chlorophylls $a$ and $b$ of leaf extract in different solvents. Biochem. Soc. Trans. 11, 591-592.

Lurie, S. and E. Pesis (1992). Effect of acetaldehyde and anaerobiosis as post harvest treatment on the quality of peaches and nectarines. Post. Biol. \& Tech.nol. 1: 317326.

McGuire, R.G. (1992). Reporting of objective color measurements. Hortscience 27: 1254- 1255.

Medllicott, A. P.; J. B. Reynolds and A.K. Thompson (1986). Effects of temperature on the ripening of mango fruit
(Mangifera indica L. var. Tommy Atkins).J. of the sci., of Food Agric.37:469-474.

Miller, G.L.( 1959). Use of dinitrosalicylic and reagent for determination of reducing sugar. Analytical Chemistry, 31: $426-428$

Montoya, M.M.; J.L. De La Plaza and V. L. López-Rodriguez Rodriguez (1994). Electrical Conductivity of Avocado Fruits During Cold Storage and Ripening. Lebensm. Wiss. Technol. 27:29-33.

Montoya, M.M., Plaza, J.L., Lopez-Rodriguez, V., 1994. An improved technique for measuring the electrical conductivity of intact fruit. Lebensm. Wiss. Technol. 27, 34-38.

Olaeta, J.; A.I.F. Gardizabal and O. Martinezdez (1986).Seasonal changes in oil content and its relation with palatability in fruits of avocado pear (Persea americana Mill.) Agric. Tecnica., 46 (3): 365-367.

Ornelas-Paz, J. De, J. ; E. M. Yahia and, A.A. Gardeab (2008). Changes in external and internal color during postharvest ripening of 'Manila' and 'Ataulfo' mango fruit and relationship with carotenoid content determined by liquid chromatography-APcl+-time-of-flight mass spectrometry. Post. Biol. \& Tech. 50: 145-152

Palapola ,Y. ; P. S. Ketsa, D. Stevenson, J.M. Cooney, A.C. Allan and I.B. Ferguson (2009). Color development and quality of mangosteen (Garcinia mangostana L.) fruit during ripening and after harvest. Post. Biol. \& Tech. 51: 349-353.

Pesis, E. and R. Ben-Arie (1984). Involvement of acetaldehyde and ethanol accumulation.

Robert, E. P. and J. C. Nancy (1983). Postharvest Variation in Cell Wall-Degrading Enzymes of Papaya (Carica papaya L.) during fruit ripening. Plant Physiol., 72:382-385.

Rouse, A. H. and C .D. Atkins (1955). Pectinesterase and pectin in commercial citrus juice as determined by methods used at the Citrus Experiment Station. Fla. Agr. Exp. Sta. Bull. 570:1-19.

Sarang, S. ; S. K. Sastry and L. Knipe (2008). Electrical conductivity of fruits and meats during ohmic heating. Journal of Food Engineering 87: 351-356

Steel, R. G. and J. H. Torrie (1980). Principles and Procedures of Statistics: A Biometrical Approach. $2^{\text {nd }}$ Ed. McGraw-Hill Book Co., New York, NY.

Vaheri, M.P.; M.E. Vaheri and V.S. Kappinen (1979). Formation and release of cellnloyticenzymes during growth of trichedermareesei on cellobiose and glycerol. Eur. J. Appl. Microbial. Biotech. 8: 73-80.

Woolf, A.B. and W.A. Laing (1996). Avocado fruit skin fluorescence following hot water treatments and pretreatments. J. Am. Soc. Hort. Sci. 121: 147-151.

Zambrano J. and W. Materano (2000). Effect of hot water treatment on the post harvest quality mango (Mangifera indica Linn.).Tropical Hort., 42: 226- 231 